\title{
CONCEPT AND ITS IMPLEMENTATION DURING THE RECONSTRUCTION OF THE CHURCH OF BLESSED VIRGIN MARY IN CHOJNA
}

\author{
Maciej PŁOTKOWIAK ${ }^{1}$ \\ West Pomeranian University of Technology, \\ Construction and Architecture Department, Szczecin, Poland
}

\begin{abstract}
St. Mary's parish church in Chojna was erected at the turn of XIV and XVc. in a shape of three aisles, hall church without transept, completed from the west with a single tower and from the east with polygonal presbytery with an ambulatory attached. The convergence of characteristic structural and decorative features with employed ones in medieval churches being attributed to Hinrich Brunsberg's fabric resulted in such a way, that also authorship of St. Mary in Chojna was assigned to this legendary architect and master builder of late Middle Ages period. The church was destroyed by fire during WWII in February 1945 and since then had remained as an open ruin. In 1997 reconstruction procedure of the church was begun under the leadership of the author and it still continues. This text consists of the sum of experiences connected with confronting design ideas and solutions with their executions on the site during construction works.
\end{abstract}

Keywords: Brunsberg, Stüler, Płotkowiak, Nowaczyk, Chojna, St. Mary's parish church in Chojna, reconstruction

\section{HISTORY OF THE OBJECT}

Parish church devoted to Blessed Virgin Mary in Chojna was built in the late $\mathrm{XIV}$ and XV century in two stages, church was erected on the place of the

1 Corresponding author: West Pomeranian University of Technology, Construction and Architecture Department, Institute of Architecture and Planning, Department of Theory of Architecture, History and Conservation of Monuments, Żołnierska str 50, 71-210 Szczecin, Poland, e-mail: plotkowiakmaciek@wp.pl, tel.: 607083460 
object, coming from the 2nd half of XIII century, representing one of the varieties of Pomeranian granite architecture [6]. At the end of the fourteenth century, one demolished its rectangular presbytery and on this place, and to the east, there was built an eastern part of hall church, brick construction, covering three spans of the nave and polygonal chancel with bypass and circles of chapels accommodated between buttresses, retracted into the interior. The other three spans of the nave probably arose in the middle of XV century [1]. However, the implement the new tower, has never been taken, settling with the church tower of the XIII century subjected to reconstruction and elevation.

Based on the convergence of construction forms and plastic design characteristics of facade, the authorship of Chojna personage was attributed to Henryk Brunsberowy - known architect and construction master of the late medieval.

Gothic church survived in almost intact state ${ }^{2}$ to 2 nd June 1843 , when one of the pillars of endangered towers collapsed, adjacent to the nave from the west. In the period of 1859-1861 one decided to implement a new neo-Gothic tower, designed by A.Sollerai A.Stüler ${ }^{3}$. This new structure built almost entirely of brick reached an impressive height of approximately $100 \mathrm{~m}$.

In 1932-1933, a neo-Gothic tower remained in such a bad state that one decided to strengthen and reconstruct it, leading to deformation of its original structure ${ }^{4}$.

\section{STATE OF PRESERVATION}

In 1945, as a result of fire ${ }^{5}$ roof trusses, arches and nine pillars between the naves as well as equipment of the nave body were destroyed, as well as the cupola crowning the tower and all the ceilings in its interior. Whereas, perimeter walls and vaulted chapels were preserved, as well as galleries located between buttresses, retracted inside, in the main body and ambulatory, and the construction of the tower to a height of approx. $80 \mathrm{~m}$ above the surrounding area.

\footnotetext{
${ }^{2}$ the inevitable changes included the construction of new tower cupolas and were the result of commemorative foundation inside the church

${ }^{3}$ in 1842 August Stüler was appointed royal architect and remained a leading architect of the Kingdom of Prussia during the construction of the tower in Chojna. Amazement is the fact of drafting him to the team that draw up the new tower project of the church in a provincial town.

${ }^{4}$ reconstruction was conducted by Erich Blunck - one of the founders of the avant-garde German architecture; probably that is why the copula was a feature of early modernism, like the cupola of the Nikolassee church of the same author

${ }^{5}$ according to P.Zalewski [10] fire took place on 16 February 1945
} 


\section{THE DESIGN STUDY FROM THE YEARS 1952-1960}

The first draft of the facility protection prepared in 1952 Eng.Witkiewicz of PKZ in Torun $[2]^{6}$.

In $1956^{7}$ the church was protected by law. Shortly after this event, another attempt was made to secure ruins. The project by A.Gruszecki and J.Widawski from the Department of Architecture of Polish Warsaw University of Technology was developed in 1960. [2] In this framework, one assumed security and access to the object to visit in the form of permanent ruins of repair if necessary and to cover the walls and vaults crown with a reinforced concrete slabs. One admitted the possibility of introducing new elements provided they would harmonize with the original surroundings and allows them to be identified and defects repaired by means of original material, restoring a part of vaults and tribune's railings, rebuilding and pointing surface of the walls and floor restoration. Access to the interior of the church for visitors was provided through the portal in the southern facade, originally leading to the sacristy. The remaining holes were intended for closure by the bars. One left the idea of introduction of the lawn inside the ruins, and surface routes were designed using concrete slabs.

\section{PROTECTION OF RUINS IN YEARS 1966-1970}

Implementation of the project was introduced during the years 1966-1970 [3]. The total work intended in the project documentation had never been carried out. One managed to do only the work that restored the original state of buttresses, damaged during cleaning works in $1957^{8}$, rebuild three vaults spans above chapels and a gallery of an ambulatory, introduce the reinforced concrete plates securing preserved ceilings above the gallery in the ambulatory and parts of the nave body and the chapel of St. Mary's, as well as install bars on the ground floor holes. Probably due to the lack of such essential elements of the development such as stairs to the gallery and stairs in the tower, ruins had never

\footnotetext{
${ }^{6}$ One provided actions leading to ad hoc technical protection of ruins, inter alia, through the introduction of reinforced concrete collars to crown the walls. However, implementation of the plans had not been taken.

7 entry in the register of monuments under No. 86, the decision Kl.V.-0/71/56 dated 4 May 1956. 8 in the course of cleanup work performed in ruins from the date of November 15, 1956 ordered by Conservation Officer, one carried out among others the demolition of three between nave pillars that underwent rotation and rested entirely in an inclined position and leaned on the crown of the peripheral walls. Resigning from the postulated technology of gradual demolition and pulling ambulatory pillar with a tractor, caused the crash, during which the mass of the wall hitting the wall at the chapel in the basement, beat inertia retracted into the interior buttresses and cut her at the base with the shift to the east of approx. $15 \mathrm{~cm}$.
} 
been made available to the public. And after discontinuation of works, the object was left to its fate.

It should be noted that technical treatments, which one managed to achieve in the ruins of the Chojna church during the years 1966-1970 fulfilled its basic task, that is-they much delayed natural processes of degradation of the ruins. This, above all, applies to the ambulatory buttresses retracted inside, which thanks to careful rebuilding remains a stable system even today. Design assumptions also met reinforced concrete slabs placed over the preserved vaults. All such secured vaults were preserved in better or worse shape, while the unprotected vaults underwent a spontaneous collapse.

\section{THE CONSERVATION STATE OF FACILITY IN 1990}

At the start of 1990 the discussions leading to the settlement of the object security concept, the ruin of the church of St. Mary in Chojna remained exposed to the elements for 45 years. The property was subjected to gradual devastation,

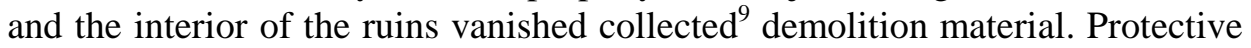
structures made in the years 1966 to 1970 were decapitalised, lost a large part of the features intended to protect the buildings, and even contributed to the deterioration of the building ${ }^{10}$. On the crown of the walls there was a lush vegetation growth. The construction of the peripheral walls of the nave body showed signs of rapid acceleration of destructive processes in the form of numerous local failures of the grain parts of the wall.

\section{STRATEGY FOR RECONSTRUCTION}

These observations led to the recognition of the ruins of the nave as the object directly threatened and subordination of further actions to the requirement of its security as soon as possible. The decision was made to divide the investment into three main stages:

- Stage I: including the protection of the medieval main body

- Stage II: intended for the renovation and restoration of neo-Gothic tower

- Stage III: concerning interior design of the main body.

\footnotetext{
9 during the cleaning works of the 50 s of $\mathrm{XX}$ century in ruins there were stored significant amounts of original brick and fittings recovered from the rubble

${ }^{10}$ destruction of covering made of tar and manhole covers in protective concrete slabs caused severe dampness of the chapel of St. Mary's vaults, while reducing the possibility of their natural drying during favourable weather
} 


\section{STAGE OF THE FIRST RECONSTRUCTION}

According to approved strategy, almost immediately, one had to accept the solution of how to secure the main body. Initially, based on the analysis of such a project from 1960, as well as operating experiences from other facilities, one rejected the concept of the facility protection in the form of a permanent ruin. Implementation adopted the simplest and, given the high degree of object behaviour, the most intrusive method of cutting wall construction from atmospheric influences with a fixed roof in the form before its destruction in 1945.

Another obstacle in the process of developing the concept of security of the main body was deficit of 9 out of 14 between-nave pillars existing originally. The solution is based on, inter alia, the experience with the reconstruction of St. Jacob church in Szczecin [4], during which one rejected the concept of terminating the interior regardless of the between-nave divisions. In connection with the reduction of the budget to grants for the sum ${ }^{11}$, which from the very beginning of the project seemed to be insufficient and poor and technical condition of the ruin, it was decided to replace the non-existing pillars with new between-nave supports that will enable them to support the roof structure. The same truss structure was solved again based on the experience from the implementation of the reconstruction of the church of St. James in Szczecin, where the use of truss steel structure composed of lattice free-articulated framework caused a number of problems and ultimately forced the admission of steel covering. So traditional wooden trusses were designed, but with increased, in relation to the calculated requirements, stiffness of the rafters.

In order to consolidate the wall structure and to accept horizontal forces transmitted by the roof truss, on the crown of the walls, one provided a collar o the reinforced concrete structure, resting on the walls through the sliding layer. Additionally, in order to counteract horizontal forces that could be transferred to the walls as a result of lengthening and shortening under the influence of temperature changes, grillage created by collars was divided (using expansion joints) into three parts.

The construction of the foundation of the new between-nave pillars was designed incorporating terms of preserving medieval footings. On footings, made of wall, one supported base plate of the new pillar resting on the ground

${ }^{11} 1911628.00$ (one million nine hundred eleven thousand six hundred twenty-eight ) PLN, by: Summary of the construction costs for the period 1989-2010, Stiftung Marienkirche in Königsberg/Neumark - Chojna, St. Mary's Church Foundation In Chojna-Königsber/Neumark, made by P.Helbich, Hannower May 27, 2011 
via 4 pillars resting on a new wall footing. Installation of foundation and new foundation pillars were designed using reinforced concrete structure.

Implementation of the project was carried out by conventional methods in years 1994-1997 ${ }^{12}$. Works began after consolidating the outline of the original between-nave pillars, since the unveiling medieval foundations non-existing between-nave pillars.

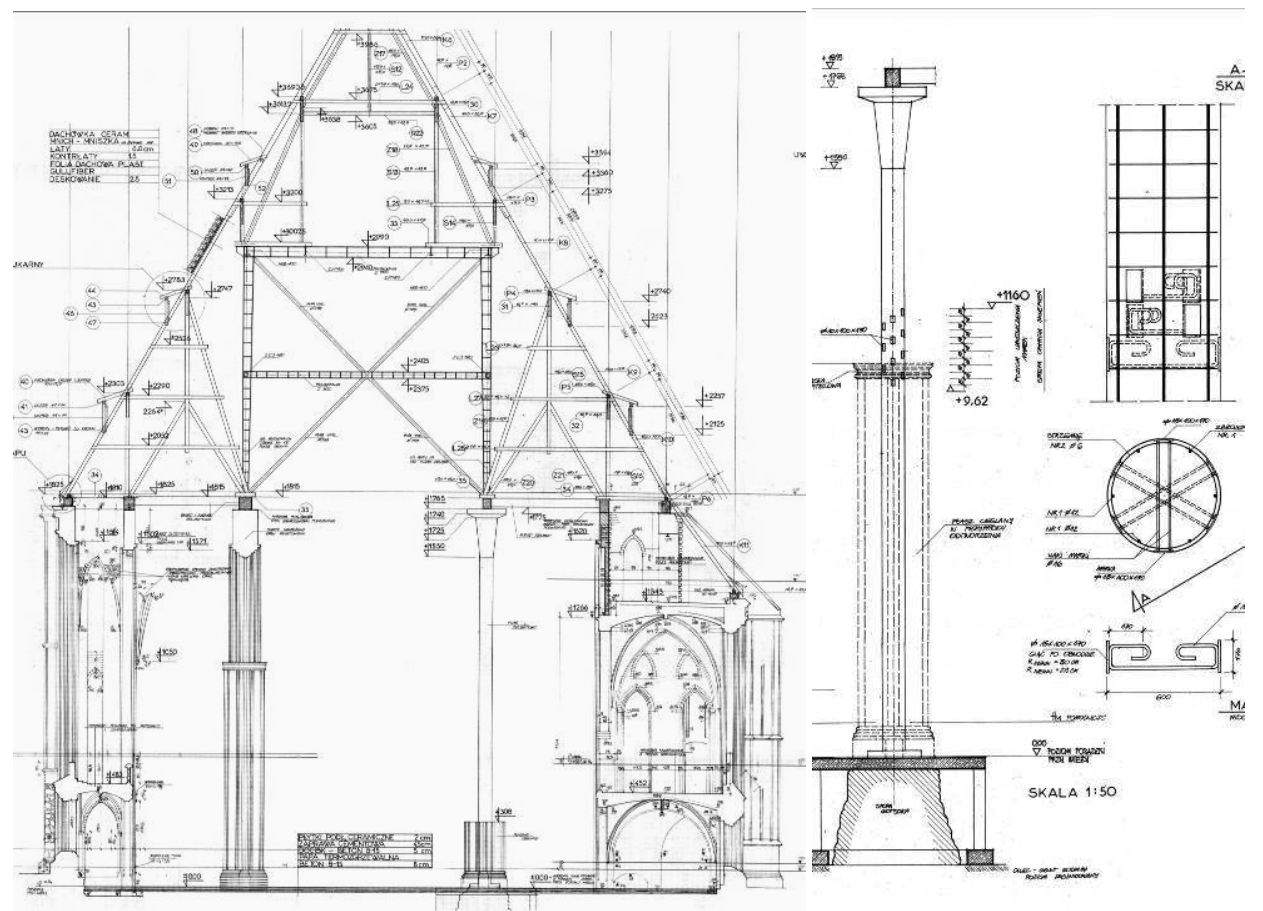

Fig. 3. A draft of the first stage from 1994; cross-section

Fig. 4. The draft of the first stage from 1994; new between-nave pillar

Next, a footing at the base and king posts at the wall feet, and at the end crowning plate. During the implementation the contractor several times, fortunately without success, tried to lead to the demolition of the medieval wall footings and replace them with new system.

Further was built a new, cylindrical between-nave supports and layout of collars on the walls crown.

Having delivered to the site and merging structure elements of the steel roof truss, it turned out that the width dimension framework provided for mounting

12 the protocol of the committee meeting on 26 October 1994, typescripts from resources of M.Płotkowiak and [5] 
above the nave did not correspond to the design assumptions and the same with the actual state. Given the slenderness of new supports ${ }^{13}$ team of authors ruled out the possibility of eccentric footing framework on supports and ordered to take the assembly after matching each of the frames individually to already made supporting elements. The frames were cut in the middle of the span, and then widened or, as needed, tighten. Removal of construction defects caused not only to shift the date of completion of works, but also led to a major increase in costs $^{14}$, which almost collapsed financing of the investment.

Wooden truss was built without any major obstacles, but as a result of haste ${ }^{15}$ in a partially asymmetric system with respect to the steel structure: on the north side bottom supports of crowning trusses of three-suspension system instead of on the bar axis coupling steel frames, they were found much overhung in front of it. Construction safety was achieved by strengthening the support foundations by means of bilateral coverings, and then one made roofing using classic ceramic tile of ridge type, laid on lime mortar with the addition of pig bristles. Installation of the roofing was preceded by the quality survey of the tile samples provided for the construction site ${ }^{16}$.

From the perspective of almost twenty years, which have passed since the completion of the first phase of reconstruction of the Chojna parish church, adopted strategy can be considered appropriate. At the moment, the primary issue for the fate of all churches is the lack of utility, which is a derivative of serious trouble in the ongoing maintenance and progressively worsening technical condition of the systems introduced in order to protect the object.

\section{SECOND PHASE OF THE RECONSTRUCTION}

The impulse to start the second phase of work was sparked in 1997 by the failure of one of the steel clamps which one fastened a brick spire tower during construction safety works in years 1932-1933. This seemingly innocuous accident, raised concerns about the stability of the whole structure with a total height of $80.54 \mathrm{~m}$. The further fact, intensifying emotions, was the location of multi-family residential buildings and the provincial road at a distance not exceeding the height of the tower ruins, that is- in the danger zone consequences of a potential construction disaster of the tower.

\footnotetext{
${ }^{13}$ supports height $\mathrm{h}=17.65 \mathrm{~m}$ at shaft diameter of $\varnothing=0.60 \mathrm{~m}$

${ }^{14}$ conditioned by the necessity of greatly extending the crane's work

${ }^{15}$ abandoned prior installation of the materialization of strech course

16 Prüfungeszeugnis Nr M.5131, Amtliche Materialprüfanstalt für Steine und Erden, Dr.Ing.H.Dörr, Clausthal-Zellerfeld 12 Juni 1995
} 
Following an inspection of scaffolding and laboratory studies of samples of building materials technical condition of rectangular lower part of the tower was considered good. However, the state of the upper octagonal section was defined as an emergency with the imminent hazard of the building catastrophe. Its wall construction remained flawed by nature, furthermore weakened as a result of demolition, heavily cracked, and mortar exhibited a low endurance. In the initial phase of developing the concept of ruins security of the tower, one seriously took into account the need to demolish the whole upper part of the tower ${ }^{17}$.

Ultimately, however, it was decided to protect the tower divided into 2 stages:

- stage IIa: was to safeguard endangered parts by using the system in a form of the outer shell of the rod construction in reinforced concrete structure,

- stage IIb: was to hide security system under a layer of the copula cover.

The task of the new protection structure was the consolidation of cracked walls, taking the spire bending forces under the influence of horizontal forces and preventing resonance phenomena. Its support was provided on the lower, rectangular part of its body using the reinforced concrete slabs resting on the ceiling placed above the floor clock during protecting works in the years 19321933.

Layout and cross -section of the security system components were designed taking into account primarily the strength and durability requirements ${ }^{18}$ and finally aesthetic requirements.

The introduction of tight coverage resulted from the need to cut off the walls of adverse weather conditions, and also to limit the damage caused by the thermal motions of the structure. One also nursed hope to restore the original artistic expression of the tower, destroyed in the 30 s of the twentieth century.

Raising funds, which enabled the financing of the project, facilitated the closing of the regional road running in the immediate vicinity of the tower. Implementation of phase IIa was carried out in 1998-1999 by traditional methods.

In the situation of stabilizing the object, at the turn of 1999 and 2000, one designed and implemented restoration of non-existing, since 1945, coping of the

\footnotetext{
17 The reason for conducting security operations in 1932-33 was the weakness and failure of the upper part of the tower. It therefore seemed that structures, brought again to the state of emergency, can no longer be saved.

${ }^{18}$ in connection with the loosening of the quoins of reinforced concrete framework construction built into the interior of the tower in years 1932-1933 to anchor the final copula, probably as a result of exposure to high temperatures during a fire in 1945, the cross-section of bars of the new security system was designed with rounding corners
} 
tower spire. The core of the cover element was designed as a steel structure welded using closed mouldings.

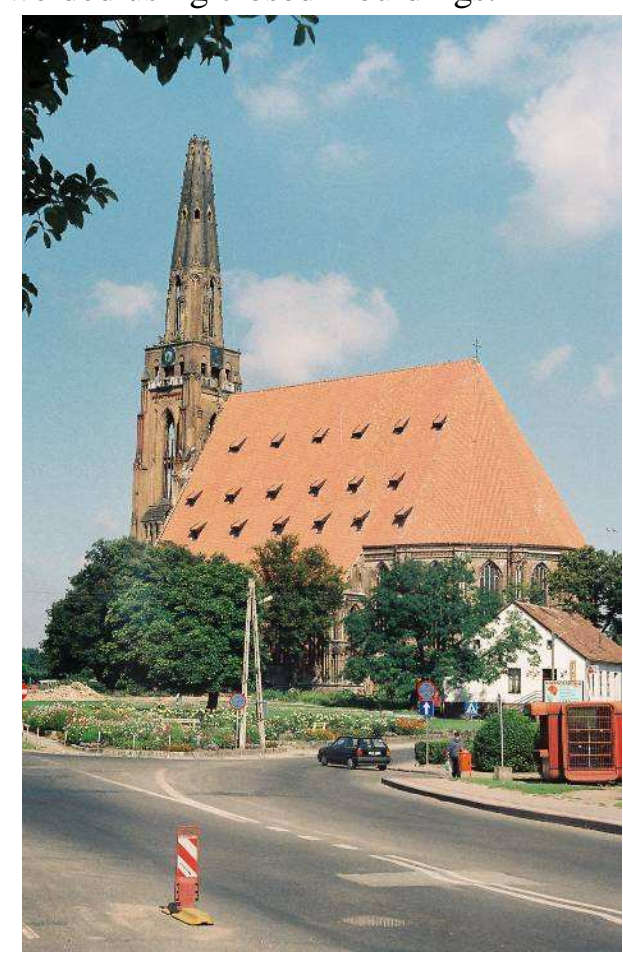

Fig. 7. Church at the end of the I stage of reconstruction; view from south-east

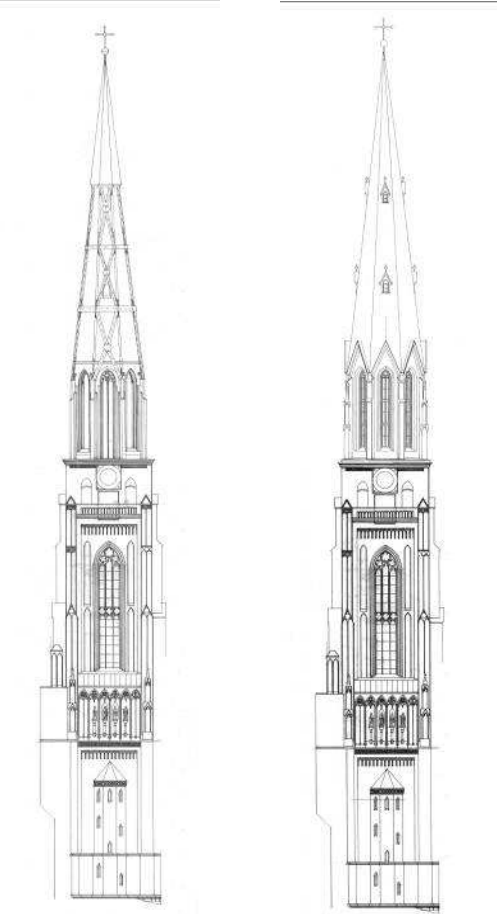

Fig. 8. Project of 1999 and 2001 of stage II of reconstruction; north elevation tower

On them, one planned anchoring a wooden structure and surface shuttering. The tower received a total height of $98.0 \mathrm{~m}$ and a spectacular appearance of sheet metal coping installed on a structure with tight-fitting security system of upper octagonal part of the block.

In 2001 one prepared the documentation for the execution of the stage $\mathrm{Ilb}^{19}$. The scope of the proposed treatments included: introduction in the interior of the tower-roofs systems and stairs connecting them and making coverage of copper sheet on forms with the introduction of design elements referring to the original artistic detail of neo-Gothic tower.

Implementation was carried out in the period of 2002-2003. Due to financial constraints, one had to remove from the crucial terms of order the whole of the

\footnotetext{
${ }^{19}$ compilation: object: Church of the Virgin Mary in Chojna, subject matter.: reconstruction and adaptation of the tower, technical security phase II, the authors.: Mgr Eng. Arch. M.Płotkowiak, Mgr.Eng.Arch. I.Całus, Dr. Eng. S.Nowaczyk, Mgr.Eng. M.Hamberg, Szczecin 2001.
} 
works to be carried out in the lower rectangular part of the tower body. As a result of unjustified fears about the stability of the upper, octagonal part of the tower, one also did not remove walls, which filled in the past ${ }^{20}$ four of the eight slender, lance-shaped windows at the base of the spire.

In 2005 it was decided to prepare documentation for the completion of stage IIb of works execution in the church tower ${ }^{21}$. The scope of tasks included changing of functional solutions in the interior of the lower, rectangular part of its body, designing clock floor for observation deck and repair of facades. In connection with granting usage to rooms inside the tower, one solved the issue of fire, inter alia, by the introduction of smoke installation on emergency exit and the use of fire zones.

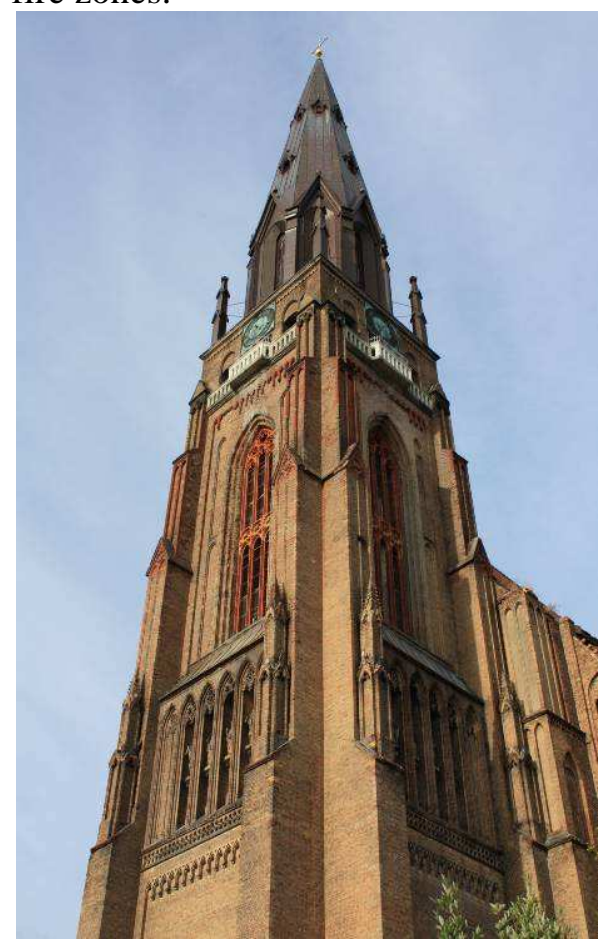

Fig. 9. Church after completion of II stage; photo by M. Płotkowiak

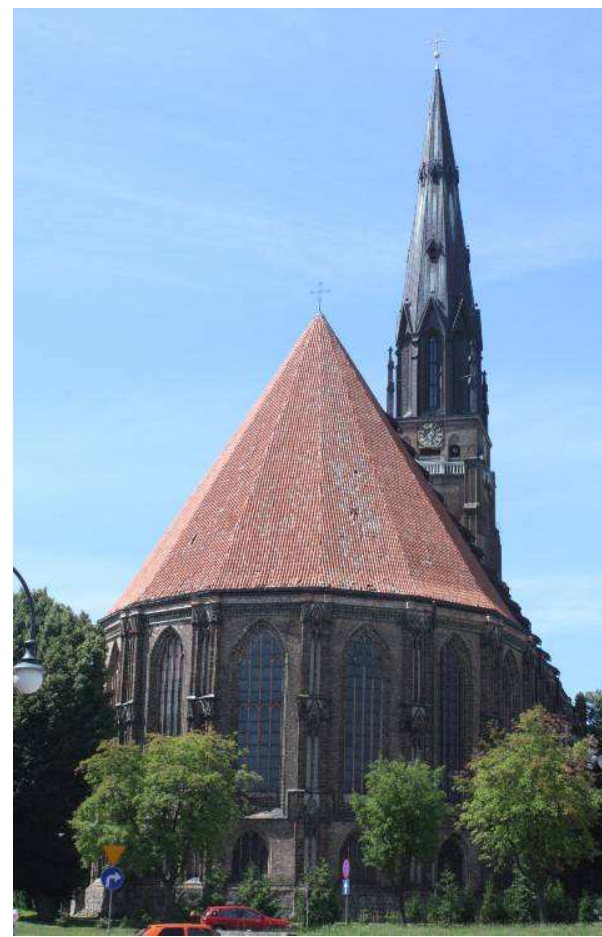

Fig. 10. Church after completion of II second stage; photo by M. Płotkowiak

\footnotetext{
${ }^{20}$ in the course of the safety works in years 1932-1933

${ }^{21}$ compilation: object: Church of the Virgin Mary in Chojna, subject matter.: reconstruction and adaptation of the tower, technical security phase II, replaceable solutions: the authors.: Mgr. Eng. Arch. M.Płotkowiak, Mgr.Eng.Arch. I.Całus, Dr. Eng. S.Nowaczyk, Mgr.Eng. M.Hamberg, Szczecin 2005
} 
Construction works were carried out in the years 2007-2009. Their scope was limited to the minimum necessary to allow the use of the observation deck. So until the end of stage IIb there remains to be done maintenance of lower elevation, rectangular part of the body and minor works inside the tower. The results of the observation of the tower structure fully confirm the desirability of treatments previously entered into force on stage II of the implementation.

\section{III STAGE OF RECONSTRUCTION}

One still had not developed the concept of action in stage III of works in the church. The current user of the object ${ }^{22}$ has been trying to push through a solution by reconstructing the vaults in their form before destruction in 1945 . The author of this statement is opposed to this idea ${ }^{23}$.

\section{REFERENCES}

1. Architektura gotycka $w$ Polsce, pod red. T. Mroczko i M. Arszyńskiego, Katalog zabytków pod red. A.Włodarka, Warszawa 1995, s.46-47.

2. Gruszecki A., Widawski J.: Ruina jako obiekt turystyczny [w:] Ochrona Zabytków, kwartalnik 2(69)XVIII Warszawa 1965, s.14.

3. Kwilecki S., Płotkowiak M.: Odbudowa kościoła NMP $w$ Chojnie jako przykład koncepcji konserwacji monumentalnej architektury ceglanej [w:] Cegła $w$ architekturze środkowo-wschodniej Europy, pod. red. M. Arszyńskiego i M. Mierzwińskiego, Malbork 2002, s.134-147.

4. Latour S.: W oczach ucznia [w:] Kwartalnik Architektury i Urbanistyki, tom XXXVIII, zeszyt 3-4, Warszawa 1994.

5. Płotkowiak M.: Problemy odbudowy kościota farnego NMP w Chojnie [w:] Miasto Historia $i$ Wspótczesność, materiaty pokonferencyjne międzynarodowej konferencji naukowej, Szczecin 2001, s.123.

6. Świechowski Z., Architektura granitowa Pomorza Zachodniego w XIIIw., Poznań 1950, s.3-5.

7. Zalewski P., Społeczeństwo obywatelskie i jego rola w ochronie dziedzictwa kulturowego na zachodnim pograniczu Polski-wprowadzenie $w$ problematyke [w:] Społeczeństwo obywatelskie, a ochrona zabytków na pograniczu polsko-niemieckim, pod red.P. Zalewskiego i B.Bielenis-Kopeć, materiały z konferencji naukowej Gubin 31.05-2.06.2012, s.25.

\footnotetext{
${ }^{22}$ church remains lent for a period of 50 years Stiftung Marienkirche in Königsberg / Neumark Chojna, St. Mary's Church Foundation in Chojna- Königsber / Neumark

${ }^{23}$ first broader statement on this subject is included in [4]
} 


\section{KONCEPCJA I JEJ REALIZACJA W TRAKCIE ODBUDOWY KOŚCIOŁA PW. NMP W CHOJNIE}

\section{Streszczenie}

Kościół farny pw. NMP w Chojnie wzniesiono z cegły na przełomie XIV i XVw., na miejscu starszego obiektu, jako trójnawową, beztranseptową halę zamkniętą od strony zachodniej pojedynczą wieżą, a po stronie wschodniej poligonalnym prezbiterium z obejściem. Zbieżność charakterystycznych form konstrukcji z wciągniętymi do wnętrza przyporami oraz cech wystroju plastycznego elewacji artykułowanych dekoracyjnymi lizenami z występującymi w obiektach łączonych z działalnością warsztatu Henryka Brunsberga spowodowały, że autorstwo chojeńskiej fary przypisano temu legendarnemu architektowi i mistrzowi budowlanemu późnego średniowiecznego. Kościół został zniszczony przez pożar 16 lutego 1945 r. i pozostawał w stanie otwartej ruiny. Zachowały się murowane ściany obwodowe wraz ze sklepieniami obwodowych: kaplic i empory zlokalizowanych pomiędzy wciągniętymi do wnętrza przyporami w korpusie nawowym i ambicie oraz konstrukcja wieży do wysokości ok. $80 \mathrm{~m}$ nad otaczającym terenem. Począwszy od 1997r. obiekt poddawany jest stopniowej odbudowie pod kierunkiem autora. Tekst niniejszy stanowi zapis doświadczeń z konfrontacji koncepcji działania i szczegółowych rozwiązań projektowych $\mathrm{z}$ wynikami ich realizacji na budowie.

Słowa kluczowe: $\quad$ Brunsberg, Stüler, Płotkowiak, Nowaczyk, Chojna, kościół mariacki w Chojnie, odbudowa

Editor received the manuscript: $21.03 .2015 \mathrm{r}$. 